\title{
Day of Surgery Cancellation in Urology at a Public Tertiary Hospital and a Private Specialist Hospital
}

\author{
Mathew Yamoah Kyei, James Edward Mensah, Lemuel Davies Bray, Foli Ashiagbor, \\ Joseph Awuku-Asabre Bernard Toboh
}

Department of Surgery and Urology, School of Medicine and Dentistry, College of Health Sciences, University of Ghana, Accra, Ghana

Email: atobray@yahoo.com

How to cite this paper: Kyei, M.Y., Mensah, J.E., Bray, L.D., Ashiagbor, F. and Toboh, J.A.-A.B. (2017) Day of Surgery Cancellation in Urology at a Public Tertiary Hospital and a Private Specialist Hospital. Open Journal of Urology, 7, 22-29. http://dx.doi.org/10.4236/oju.2017.71004

Received: December 9, 2016

Accepted: January 15, 2017

Published: January 18, 2017

Copyright $\odot 2017$ by authors and Scientific Research Publishing Inc. This work is licensed under the Creative Commons Attribution International License (CC BY 4.0).

http://creativecommons.org/licenses/by/4.0/ (c) (i) Open Access

\begin{abstract}
Background: There is a high variability in the reasons for cancellation of elective urological surgery cases. Case cancellation rate is expected to be high in the Public Health System with perceived inefficiencies compared to private facilities in the same developing economy. Aims and Objectives: This comparative analysis was to determine the case cancellation rate and the reasons for cancellation of elective urological surgeries in a public tertiary hospital and a private specialist hospital in Accra. This is intended to form a basis for interventions aimed at reducing the case cancellation rate. Methods: This was a retrospective analysis of prospectively collected data on Day of Surgery cancelled elective urological cases from September 2014 to October 2015 at the urology unit of the Korle-Bu Teaching Hospital (KBTH), a public Tertiary Hospital and the Trust Specialist Hospital (TSH), a privately managed hospital in Accra. The reasons for case cancellation were categorized into structural factors, patient factors and process factors. Results: There was no significant difference between the case cancellation rate for elective urological cases at KBTH and the TSH which were $20.8 \%$ and $17.1 \%$ respectively $(\mathrm{p}=0.317)$. For $\mathrm{KBTH}$, the reasons for cancellation of elective urological cases were due to structural factors in 11/117 (9.4\%), patient factors in $15 / 117(12.8 \%)$ and process factors in $91 / 117$ (77.8\%) which was due mainly to surgery running late. At the TSH, the reasons were due to structural factors in $1 / 29$ (3.4\%), patient factors in 27/29 (93.1\%) mainly due to patient not turning up and process factors in $1 / 29$ (3.4\%). Conclusion: The case cancellation rate of elective urological surgeries in both the Public Tertiary Hospital and the Private Specialist Hospital were high with no significant difference between the two. However, in the Public Tertiary Hospital, process factors predominated as the cause of these cancellations while patient factors were the predominant cause
\end{abstract}


in the privately managed facility. Exposure of theater managers in public facilities to management practices in privately run facilities should be encouraged to help improve the efficiency of the public facilities.

\section{Keywords}

Elective Urological Surgery, Case Cancellation, Public Tertiary Hospital, Private Specialist Hospital

\section{Introduction}

Elective surgical case cancellation refers to any surgical case that is booked into the operation theatre list on the day prior to surgery but is not operated upon as scheduled [1]. Unanticipated cancellation of scheduled elective operations leads to a decrease theatre efficiency, waste of theatre time and resources, increases hospital expenses and a potential revenue loss to the institution [2] [3] [4]. This is undesirable in low resource economies with limited health budgets. Case cancellations have also been noted to create financial burden for patients and their families as well as causing emotional stress and a negative perception of quality of care [3] [5] [6] [7]. There is a resultant patient dissatisfaction and decreased staff morale when cases are cancelled [4]. In the setting of a tertiary Teaching Hospital, high cancellations of elective surgeries also affect medical education, training and skills acquisition by Residents and other students in training. Elective surgical case cancellation rates as high as $13 \%$ have been noted [8] and these rates vary with specialty with urology being one of the highest [9] [10]. The reasons for cancellation of elective surgical cases which may be patient-initiated or hospital-initiated are multifactorial [11] [12]. These reasons can also be assessed using the Donabedian's quality of care framework [13] which was also used by Leslie RJ et al. [8] and presents a relationship between Structure, Process and Patient outcomes. The factors may be categorized into (1) structural factors such as, limited operating rooms and full recovery ward; (2) patient factors such as patient not turning up or not adhering to pre-operative instructions; and (3) process factors such as surgery running late and mechanical faults with theatre equipment. Various interventions have been instituted in some centers aimed at reducing the Day of surgery case cancellation rates such as institution of preadmission clinics aimed at optimizing patients for surgeries [14] [15]. Case cancelation rate has been noted to vary with the hospital size and the type of service offered [16]. Of interest in developing countries is the perceived inefficiencies in the Public health system compared to the Private set ups. Thus, the case cancellation rate as observed in the private health set up may defer from that of the public sector and might bring to the fore other local and regional interventions that might be useful in reducing the case cancellation rates. As far as we know, no study has compared the case cancellation rates between that of the Public Specialist/Tertiary Hospital and private Specialist Hospital that offer tertiary care 
in the West Africa sub region. The objective of this study was to determine the reasons for elective urological case cancellation in a public tertiary hospital and a private specialist hospital in Accra so as to identify modifiable factors and differences that would provide a basis for intervention to reduce the case cancellation rates.

\section{Materials and Methods}

This study was a retrospective analysis of prospectively collected data on Day of Surgery cancelled elective urological cases from September 2014 to October 2015 a fourteen month period at the urology unit of the Korle-Bu Teaching Hospital (KBTH), a public tertiary hospital and the Trust Specialist Hospital (TSH), a privately managed hospital that offers tertiary services in Accra, Ghana.

Scheduled elective urological cases at these centers as per theater list submitted to the theaters, ward and departmental administration over the period under consideration were retrieved and documented. The record books for documenting any cases that were cancelled including the reasons for the cancellation were also obtained for analysis. The reason for cancellation was documented by the receiving theater nurse (reception nurse desk). However since no coding has been made at the two institutions, it is stated as best as understood by the receiving nurse. The consultants in charge were interviewed for any additional information they could recall. For this study, Elective Urological surgical case cancellation was defined as any case that was booked into the operation theatre list that had been circulated to departmental administration, the admission wards, anaesthetic department, the theater and the recovery wards on the day prior to surgery but was not operated upon on the day of surgery as scheduled. The reasons were categorized into structural factors, patient factors and process factors.

Ethical clearance and permission was granted from KBTH and TSH before the study and publication of the findings thereafter.

Emergency cases were excluded from this study.

The data were analyzed using the Statistical Service Package for the Social Sciences (SSPS) version 21 and presented as descriptive statistics using ratios and percentages. Categorical data were compared using the chi square test.

\section{Results}

A total number of 673 elective urological cases were scheduled at the Korle $\mathrm{Bu}$ Teaching Hospital over the period of which 140 cases were cancelled with a case cancellation rate of 20.8\%. At the Trust Specialist Hospital, a total of 211 cases were scheduled for surgery and 36 cases cancelled giving a case cancellation rate of $17.1 \%$. The difference was not significant $(\mathrm{p}=0.317)$ (Table 1$)$.

Analysis of the factors resulting in case cancellation of elective urology surgeries at the KBTH, a public facility, revealed that process factors were the commonest cause with surgeries running late as a result of late start of procedures or delays in case turn around being most encountered 91/117 (77.8\%) (Table 2).

Analysis of the factors resulting in case cancellation of elective urology surgeries 
Table 1. Table depicting scheduled Elective Urologic Surgeries and case cancellation rate.

\begin{tabular}{cccc}
\hline Hospital & Scheduled cases & Cancelled cases & $\begin{array}{c}\text { Case Cancellation } \\
\text { Rate (\%) }\end{array}$ \\
\hline Korle Bu Teaching Hospital (KBTH) & 673 & 140 & 20.8 \\
Trust Specialist Hospital (TSH) & 211 & 36 & 17.1 \\
\hline
\end{tabular}

Table 2. Reasons for Case cancellation at the Korle Bu Teaching Hospital (KBTH) $[\mathrm{n}=$ 117].

\begin{tabular}{|c|c|c|c|c|c|}
\hline Structural factors & No. & Patient Factors & No. & Process factors & No. \\
\hline $\begin{array}{l}\text { Full recovery ward/ } \\
\text { step down bed }\end{array}$ & 2 & $\begin{array}{l}\text { Medical reasons- } \\
\text { Pending dialysis }\end{array}$ & 2 & Surgery running late & 70 \\
\hline No ICU bed & 2 & $\begin{array}{c}\text { Medical reasons- } \\
\text { uncontrolled } \\
\text { hypertension }\end{array}$ & 4 & No blood & 7 \\
\hline $\begin{array}{l}\text { Pulse oximeters } \\
\text { defective }\end{array}$ & 7 & $\begin{array}{l}\text { Medical Reasons- } \\
\text { acute asthma }\end{array}$ & 1 & Low $\mathrm{Hb}$ & 4 \\
\hline $\begin{array}{l}\text { Lack of running } \\
\text { water }\end{array}$ & 2 & Patient not fit & 1 & Patient not NPO & 2 \\
\hline Unstable electricity & 1 & $\begin{array}{l}\text { Patient refuse } \\
\text { procedure }\end{array}$ & 1 & Incomplete work up & 6 \\
\hline \multirow[t]{3}{*}{$\begin{array}{c}\text { Theater logistics/ } \\
\text { equipment break } \\
\text { down }\end{array}$} & 1 & $\begin{array}{l}\text { Patient did not } \\
\text { show up }\end{array}$ & 2 & $\begin{array}{c}\text { No anaesthesia } \\
\text { available }\end{array}$ & 1 \\
\hline & & $\begin{array}{c}\text { Done previously as } \\
\text { emergency }\end{array}$ & - & $\begin{array}{l}\text { Failed regional } \\
\text { anaesthesia }\end{array}$ & 1 \\
\hline & & & & $\begin{array}{l}\text { Moved to another date } \\
\text { surgeons office }\end{array}$ & - \\
\hline Total (\%) & $15(12.8)$ & & $11(9.4)$ & & $91(77.8)$ \\
\hline
\end{tabular}

at the $\mathrm{KBTH}$, a public facility, revealed that process factors were the commonest cause with surgeries running late as a result of late start of procedures or delays in case turn around being most encountered 91/117 (77.8\%) (Table 2).

The reasons for the cancellation of 23 cases were not stated, hence excluded from data analysis giving a reporting rate of $83.6 \%$. In the TSH, a privately managed facility, patient factors as related to the patients inability to mobilize the needed funds in time or delays in getting pre-approval by insurance companies were the commonest cause 27/29 (93.1\%) (Table 3).

Of the type of surgeries that were cancelled, major surgeries were the commonest cancelled at the KBTH while endoscopic procedures were commonest cancelled at the TSH (Table 4).

\section{Discussion}

Getting patients ready for surgery involves preparation that requires mobilization of resources by both the health facility and the patient. Thus, getting the surgery carried out on time allows for effective utilization of the available resources and improved patient outcomes [2]. It also enhances patient satisfaction and help boost staff morale [4]. As has been noted, cancellation rates vary with 
Table 3. Reasons for case cancellation at the Trust Specialist Hospital (TSH) [n = 36].

\begin{tabular}{|c|c|c|c|c|c|}
\hline Structural Factors & No. & Patient Factors & No. & Process Factors & No. \\
\hline $\begin{array}{l}\text { Full recovery ward/ } \\
\text { step down bed }\end{array}$ & - & $\begin{array}{l}\text { Medical reasons- } \\
\text { Pending dialysis }\end{array}$ & - & Surgery running late & - \\
\hline No ICU bed & - & $\begin{array}{l}\text { Medical reasons- } \\
\text { uncontrolled hypertension }\end{array}$ & 1 & No blood & - \\
\hline $\begin{array}{l}\text { Pulse oximeters } \\
\text { defective }\end{array}$ & - & $\begin{array}{c}\text { Medical Reasons- } \\
\text { acute asthma }\end{array}$ & & low haemoglobin & - \\
\hline $\begin{array}{c}\text { Lack of running } \\
\text { water }\end{array}$ & - & Patient not fit & 1 & $\begin{array}{l}\text { patient not Nil } \\
\text { per Os }\end{array}$ & - \\
\hline $\begin{array}{l}\text { Unstable } \\
\text { electricity }\end{array}$ & & $\begin{array}{l}\text { Patient refuse } \\
\text { procedure }\end{array}$ & 1 & Incomplete work up & - \\
\hline \multirow[t]{3}{*}{$\begin{array}{l}\text { Theater logistics/ } \\
\text { equipment break } \\
\text { down }\end{array}$} & 1 & Patient did not show up & 30 & $\begin{array}{l}\text { No anaesthesia } \\
\text { available }\end{array}$ & - \\
\hline & & $\begin{array}{c}\text { Done previously as } \\
\text { emergency }\end{array}$ & 1 & $\begin{array}{c}\text { Failed regional } \\
\text { anaesthesia }\end{array}$ & - \\
\hline & & & & $\begin{array}{l}\text { Moved to another } \\
\text { date surgeons office }\end{array}$ & 1 \\
\hline Total (\%) & $1(2.7)$ & & 34 (94.4) & & $1(2.7)$ \\
\hline
\end{tabular}

Table 4. Cancelled Case types.

\begin{tabular}{ccc}
\hline Case types & $\begin{array}{c}\text { Korle Bu Teaching Hospital } \\
(\mathrm{KBTH}) \text { No. }(\%)\end{array}$ & $\begin{array}{c}\text { Trust Specialist Hospital (TSH) } \\
\text { No. (\%) }\end{array}$ \\
\hline Major Surgeries & $77(55)$ & $3(8.3)$ \\
Endoscopies & $50(35.7)$ & $17(47.2)$ \\
Minor Surgeries & $13(9.3)$ & $16(44.4)$ \\
Total & $140(100)$ & $36(100)$ \\
\hline
\end{tabular}

the size of the hospital facility as well as the surgical specialty; with urological cases, ENT and cardiothoracic surgeries noted to have high cancellation rates [9] [10] [17]. For elective urological surgeries the case cancellation rate was $20.8 \%$ at the public Tertiary Hospital (KBTH) compared to $17.1 \%$ at the privately managed health facility (TSH). This figures are however high compared to up to $13 \%$ stated by Leslie et al. [8] There was however no significant difference between the case cancellation rate between the public tertiary hospital and the privately run specialist hospital that carriers out the same range of elective urological surgeries $(\mathrm{p}=0.317)$. Although there is no consensus on the acceptable rate of case cancellation when evaluating the efficiency of theatre facilities, a case cancellation rate of less than $5 \%$ is generally recommended. In New South Wales, Australia, the benchmark for booked patient cancellations on the day of surgery (for any reason) was less than $2 \%$. Cancellation due to a medical condition was set at less than $1 \%$ and for patients not attending on the day of surgery it was less than $0.5 \%$ [18]. The figures recorded in this study indicate a rather inefficient management of the theaters in both facilities compared to the bench marks. 
Process factors were the commonest cause of elective urological case cancellation at the public tertiary hospital $(77.8 \%)$. This is in variance with studies in advanced economies that found process factors as second to structural (facility) factors as most common cause of surgical case cancellations; $17 \%$ in the study by Chiu et al. [17]. Process factors are modifiable and hence provide opportunity for interventions to reduce case cancellations related to these factors at the $\mathrm{KBTH}$ where the commonest process factor for case cancellations was surgery running late (70/91). This is attributed to late starting of the surgery theater sections and a rather prolonged turnaround time leading to inability to complete the scheduled list resulting in case cancellations. The re-activation of previously installed software to monitor work flow in the theaters may be warranted at the $\mathrm{KBTH}$ as well as its installation in other public tertiary hospitals to help identify and address the delays in initiating theater sections and also reduce the turnaround time in order to minimize the occurrence of theater running late. Incomplete patient work up (6/91) was however not prominent as a process factor for case cancellation. This may be attributed to the hospital having instituted a pre-surgery anaesthetic clinic since 2000 that had led to improvements in optimizing patients for surgery. This type of intervention (pre-surgery anaesthetic clinic) is practiced in other institutions aimed at reducing the case cancellation rates with improvements recorded [8] [14] [15]. Structural factors accounted for $12.8 \%$ of the case cancellations compared to $29.5 \%$ in a study by Huda [4]. Defective pulse oximeters accounted for most of the structural issues at the KBTH.

On the other hand, in the privately managed TSH, patient factors dominated (94.4\%) with the patients not showing up being a predominant cause. This may be attributed to delays or inability to raise the needed funds in time for the procedures, the cost of which tend to be higher than pertains in the public facilities. For the patients on health insurance, there were delays in obtaining pre-surgery approval from the insurance companies that was meant to indicate their preparedness to pay for the cost of the surgery. Scheduling of patients for elective urological surgeries that takes these delays into account might help reduce the case cancellation rates in the privately managed facilities as most of these surgeries were done eventually. Worthy of note is the finding that structural factors and process factors $(2.7 \%$ and $2.7 \%$ respectively) were not important causes of case cancellation in this privately managed facility. This may be attributed to the TSH having adopted the pre-surgery assessment model as well as its efficient management of the theaters. Surgery running late was not a feature as a cause of case cancellation compared to the public tertiary facility. Exposure of theater managers in public facilities to management practices in privately managed facilities by way of internship should be encouraged to help improve the efficiency of the public facilities.

\section{Conclusions}

The case cancellation rate of elective urological surgeries in both the public tertiary hospital and the private specialist hospital were high with no significant difference 
between the two. However, while in the public hospital, process factors mainly due to theater running late predominated as the cause of these cancellations, patient factors from patients not showing up was the predominant cause in the privately run facility and was related to obtaining funding for the procedures.

We recommend exposure of theater managers in public facilities to management practices in privately run facilities in order to improve efficiency in public facilities.

\section{Acknowledgements}

Our appreciation goes to Management of the Korle Bu Teaching Hospital and the Trust Specialist Hospital for their support in facilitating access to the required records. We also thank Prof Gladys Amponsah for providing the history of the establishment of pre-anaesthetic clinic at the Korle Bu Teaching Hospital

\section{References}

[1] Dawlatly, A.A., Turkistani, A., Aldohayan, A., Zubaidi, A. and Ahmed, A. (2008) Reasons of Cancellation of Elective Surgery in a Teaching Hospital. The Internet Journal of Anesthesiology, 15, 2.

[2] Tait, A.R., Voepel-Lewis, T., Munro, H.M., Gutstein, H.B. and Reynolds, P.I. (1997) Cancellation of Pediatric Outpatient Surgery: Economic and Emotional Implications for Patients and Their Families. Journal of Clinical Anesthesia, 9, 213-219. https://doi.org/10.1016/S0952-8180(97)00032-9

[3] Ivarsson, B., Kimblad, P.O., Sjöberg, T. and Larsson, S. (2002) Patient Reactions to Cancelled or Postponed Heart Operations. Journal of Nursing Management, 10, 75 81. https://doi.org/10.1046/j.0966-0429.2001.00293.x

[4] Huda, F. (2014) A Retrospective Analysis of Reasons for Cancellation of Elective Surgery in a Teaching Hospital. International Journal of Scientific Reports, 2, 28-30.

[5] Siemens, D.R., Schulze, K.M., Mackillop, W.J., Brundage, M.D. and Groome, P.A. (2005) A Population-Based Study of the Waiting Times for Prostatectomy in Ontario. Canadian Journal of Urology, 12, 2568-2574.

[6] Kawakami, J., Hopman, W.M., Smith-Tryon, R. and Siemens, D.R. (2008) Measurement of Surgical Wait Times in a Universal Health Care System. Canadian Urological Association Journal, 2, 597-603. https://doi.org/10.5489/cuaj.974

[7] Tait, A.R., Voepel-Lewis, T., Munro, H.M., et al. (1997) Cancellation of Pediatric Outpatient Surgery: Economic and Emotional Implications for Patients and Their Families. Journal of Clinical Anesthesia, 9, 213-219. https://doi.org/10.1016/S0952-8180(97)00032-9

[8] Leslie, R.J., Beiko, D., van Vlymen, J. and Siemens, D.R. (2013) Day of Surgery Cancellation Rates in Urology: Identification of Modifiable Factors. Canadian Journal of Urology, 7, 167-173. https://doi.org/10.5489/cuaj.1345

[9] Jiménez, A., Artigas, C., Elia, M., Casamayor, C., Gracia, J.A. and Martinez, M. (2006) Cancellations in Ambulatory Day Surgery: Ten Years Observational Study. Ambulatory Surgery, 12, 119-123. https://doi.org/10.1016/j.ambsur.2005.09.002

[10] Schofield, W.N., Rubin, G.L., Piza, M., Lai, Y.Y., Sindhusake, D., Fearnside, M.R, and Klineberg, P.L. (2005) Cancellation of Operations on the Day of Intended Surgery at a Major Australian Referral Hospital. The Medical Journal of Australia, 182, 612-615. 
[11] Sanjay, P., Dodds, A., Miller, E., Arumugam, P.J. and Woodward, A. (2007) Cancelled Elective Operations: An Observational Study from a District General Hospital. Journal of Health Organization and Management, 21, 54-58. https://doi.org/10.1108/14777260710732268

[12] Haana, V., Sethuraman, K., Stephens, L., Rosen, H. and Meara, J.G.L. (2009) Case Cancellations on the Day of Surgery: An Investigation in an Australian Paediatric Hospital. ANZ Journal of Surgery, 79, 636-640. https://doi.org/10.1111/j.1445-2197.2009.05019.x

[13] Donabedian, A. (1988) The Quality of Care. JAMA, 260, 1743-1748. https://doi.org/10.1001/jama.1988.03410120089033

[14] Jones, A.R., Sandison, A.J. and Owen, W.J. (1997) The Impact of Pre-Clerking Clinics on Surgical Operation Cancellations: A Prospective Audit. International Journal of Clinical Practice, 51, 294-295.

[15] Aimakopoulos, G., Harrison, R. and Magnussen, P.A. (1998) Pre-Admission Clinic in an Orthopaedic Depart Department: Evaluation over a 6-Month Period. Journal of the Royal College of Surgeons of Edinburgh, 43, 178-181.

[16] Schuster, M., Neumann, C., Neumann, K., Braun, J., Geldner, G., Martin, J., Spies, C. and Bauer, M. (2011) CASCAES Study Group. The Effect of Hospital Size and Surgical Service on Case Cancellation in Elective Surgery: Results from a Prospective Multicenter Study. Anesthesia \& Analgesia, 113, 578-585. https://doi.org/10.1213/ane.0b013e318222be4d

[17] Chiu, C.H., Lee, A. and Chui, P.T. (2012) Cancellation of Elective Operations on the Day of Intended Surgery in a Hong Kong Hospital: Point Prevalence and Reasons. Hong Kong Medical Journal, 18, 5-10.

[18] Macario, A. (2006) Are Your Hospital Operating Rooms "Efficient”? A Scoring System with Eight Performance Indicators. Anesthesiology, 105, 237-240. https://doi.org/10.1097/00000542-200608000-00004

\section{Submit or recommend next manuscript to SCIRP and we will provide best service for you:}

Accepting pre-submission inquiries through Email, Facebook, LinkedIn, Twitter, etc. A wide selection of journals (inclusive of 9 subjects, more than 200 journals)

Providing 24-hour high-quality service

User-friendly online submission system

Fair and swift peer-review system

Efficient typesetting and proofreading procedure

Display of the result of downloads and visits, as well as the number of cited articles

Maximum dissemination of your research work

Submit your manuscript at: http://papersubmission.scirp.org/

Or contact oju@scirp.org 